\title{
5
}

\section{Public budgeting system in Taiwan: Does it lead to better value for money?}

\section{Tsai-tsu Su}

One of the major objectives of a public budgeting system-which prescribes and enforces rules for the allocation, expenditure and accounting of fiscal resources-is to maximise the value of taxpayers' money. To achieve this objective, public budgeting systems in industrialised nations have undergone several reforms during the past decades, including the performance budgeting system in the 1950s, the planning-performancebudgeting system in the 1960s, the zero-based budgeting system in the 1970s and the entrepreneurial budgeting system (or new performance budgeting system) in the 1980s. Although each reform employs different budgeting techniques and principles, all aim to safeguard taxpayer dollars in budgetary decision-making.

Similarly, Taiwan has gone through various budgetary reforms in the past decades, most notably the phase of 'democratisation of public budgeting' that began in the mid-1970s and the phase of 'effectiveness of public budgeting' starting in the mid-1990s (Su 2007). The former reform aimed to democratise budgetary decision-making, while the latter-heavily influenced by the ideologies of New Public Management (NPM) — aimed to achieve a 'small and beautiful' government and to increase the value of taxpayers' money. 
While these reforms transformed the public budgeting system in Taiwan, it remains unclear whether they met taxpayers' expectations and delivered effective budgetary allocation as promised. This is the central question explored in this chapter. The chapter begins by describing the main characteristics of the four stages in the central government's budget cycle-namely, budget preparation, legislative approval, budget execution, and accounting and audit. Second, it discusses the characteristics of local governments' budget processes. It then introduces the newly adopted budgetary reform measures such as participatory budgeting and performance auditing. The chapter concludes by discussing the prospects of the current public budgeting system achieving better value for public money.

\section{The central government budget process}

\section{Budget preparation}

The two principle budgeting bodies in Taiwan's central government are the Directorate-General of Budget, Accounting and Statistics (DGBAS) of the Executive Yuan and the Ministry of Finance. The role of the DGBAS resembles that of the Office of Management and Budget in the United States. It is the main authority that assists the country's premier in allocating budgeting resources and preparing the general budget. The MoF is responsible for estimating the revenue for the coming year and providing these estimates to the DGBAS. Based on these estimates, the DGBAS prepares the general budget proposal for the upcoming year, including budget allocations across ministries.

In the budget preparation process, the DGBAS first assigns an annual expenditure cap for each ministry. Each ministry is then required to develop its own budget estimates following the zero-based budgeting approach imposed by the DGBAS. In other words, each ministry should estimate each spending program thoroughly to reflect the latest changes in the macro-environment and respond to emerging public needs, although, in reality, many agencies in the ministries still follow an incremental or decremental budgeting model. In addition, the Budget Act 1998 stipulates that each ministry should complete a cost-benefit analysis (CBA) before submitting a budget proposal for major projects. In most cases, however, the CBA is a mere formality, and its results are seldom incorporated 
into the budget preparation process. Meanwhile, whenever a ministry formulates a big spending program exceeding a threshold level, ${ }^{1}$ it first submits it to the National Development Council for preliminary review of the demand for, feasibility, economic benefits and social impact of the program. Only when it passes this review will it be included in the ministry's budget estimates.

Each ministry submits its respective budget estimates to the DGBAS for aggregation into the central government's overall general budget proposal. The premier then convenes the Annual Program and Budget Council to review the general budget proposal. While each ministry's budget estimates generally should not exceed the expenditure cap assigned by the DGBAS, it will highlight newly required budget items that exceed the cap for discussion in the council. By law, the DGBAS must submit the central government's general budget proposal to the Legislative Yuan for deliberation before the end of August each year.

The central government's budget preparation has a few key features. First, it is a combination of top-down and bottom-up processes (Su 1996: 25-42). The DGBAS, following a top-down approach, sets an annual expenditure cap for each ministry to plan their respective budgets. But when ministries prepare their own budgets, they take a bottom-up, incremental budgeting approach, and often request additional budget support when needs arise, even if the budget goes beyond the DGBAS's expenditure cap.

Second, when compared with the budget phases described later in this chapter, this budget preparation process is less transparent. The ministrylevel budget preparation information and the meeting minutes of the Annual Program and Budget Council are not fully disclosed publicly. This makes it difficult for the public to understand how bureaucrats prepare the budget and the information on which budget allocations rely. Because of this, there is little literature concerning the budget preparation process in Taiwan.

1 Take, for example, the preliminary review of the 2017 general budget proposal. Programs that require preliminary review include individual social development programs with a total budget exceeding NT\$300 million (A $\$ 12.5$ million) and scientific development programs with a total budget of more than NT\$500 million (A $\$ 20.8$ million) or an annual budget of at least NT\$200 million (A\$8.3 million). 
Third, it may be argued that the DGBAS is occupied more with controlling the level of total spending and the budget deficit than with focusing on whether each ministry's budget allocation corresponds to the needs of the public and fulfils the principles of efficiency, effectiveness and fairness. This tendency might be attributed to Taiwan's traditional emphasis on containing taxpayers' tax burden, which is usually calculated as the ratio of total tax revenue to gross domestic product (GDP). For example, while the tax burden of the average taxpayer in Taiwan was around 12 per cent between 2010 and $2015,{ }^{2}$ the average for Organisation Economic Co-operation and Development (OECD) countries during the same period was close to 34 per cent. ${ }^{3}$ Because of the low tax revenue and the huge gap between tax revenue and spending demands, the DGBAS is forced to devote most its efforts to cutting down on expenditures and reducing the deficit, leaving the issue of cross-ministry or cross-function budget allocation as a secondary concern, which sometimes leads to allocative inefficiency.

\section{Legislative approval}

Taiwan's Constitution prescribes a presidential regime, so, like the federal government of the United States, its legislature has final decision-making power regarding the annual budgetary allocation.

However, unlike the United States, where congressional members can add or delete budget items and increase or decrease expenditures in the budget bill proposed by the White House, in Taiwan, the budget decision-making power of legislators is circumscribed by the Constitution. Taiwanese legislators cannot increase the spending in the budgetary bill presented by the Executive Yuan; they can only remove budget items or decrease expenditures.

The budget approval process that takes place in Taiwan's Legislative Yuan has long attracted media attention, especially with the recent increase in competitive party politics. Legislators focus more on gaining publicity during the budget approval process than on exercising professionalism

2 The average tax burden for taxpayers in Taiwan for fiscal years 2010-15 were 11.5 per cent, 12.3 per cent, 12.2 per cent, 12 per cent, 12.3 per cent and 12.8 per cent, respectively. The average for these years is 12.12 per cent (Department of Statistics 2017: Table 3.9).

3 The average total tax revenue as a percentage of GDP for OECD countries was 32.4 per cent for 2009, 33.4 per cent for 2012, 34.2 per cent for 2014 and 34.3 per cent for 2015 (OECD 2016: Table 1.1). 
(Rigger 1999). This has led to a highly politicised parliamentary approval process, often at the expense of rational dialogue between the ruling and opposition parties. Furthermore, legislative committees fail to fully exercise their budget review functions. When committee members cannot agree to proposed budget cuts for certain spending programs, they resort to cross-caucus negotiations-a process that is not disclosed to the public. ${ }^{4}$ Only a few legislators from the ruling and opposition parties have access to these 'secret negotiations' and, as long as one of them refuses to approve a proposal, the negotiation falls apart. In other words, each consultation participant can veto the budget, but they are not held accountable. These 'black-box' negotiations between political parties are the most criticised aspect of the budget approval process in the Legislative Yuan (Hawang 2002; Wang 2002; Chao 2005).

When legislators review the general budget proposal, they can seek professional assistance from the Legislative Budget Center (LBC), which is affiliated with the Legislative Yuan. The LBC is responsible for all research, analysis, evaluation and consultation works related to the central government's budget. In its early years, the LBC's budget assessment reports received little attention. But, since 2000, when the LBC was separated from the Legislative Consulting Office and employed more personnel, its reports have attracted a wider audience among legislators and the media, especially when the LBC issued harsh criticism of the public expenditure efficiency of the executive branch. Meanwhile, given that the core expertise of most LBC staff is in accounting and not in performance evaluation of expenditure programs, there is scope for improving the LBC's role in facilitating the public's understanding of the budgetary process and assisting legislators to play a more effective role.

Despite these issues with the budget approval process in the Legislative Yuan, it has made great strides since the authoritarian era in the budget review phase, as well as in promoting budget transparency and open government. While the party caucus consultation process is still questionable, the proceedings and budget review in all committees are now streamed live online. Through a video-on-demand system, one can also locate the public records of legislators' interpellation in legislative

4 According to the Law Governing the Legislative Yuan's Power (Article 70): 'Legislative negotiations, under the support of the Secretary General, should be documented, and voice and video recorded; the proceedings and the negotiation conclusions should be published in the official gazette.' Yet, in practice, only a summarised conclusion is announced, without any negotiation details. 
proceedings and committee meetings. This open and transparent broadcast system enhances the public accountability of the Legislative Yuan in its budget decision-making.

\section{Budget execution}

Once the general budget proposal goes through three readings in the Legislative Yuan, it is referred to as a 'legal budget' by which all ministries should abide. Many laws in Taiwan govern the budget execution process, including the Budget Act 1932, the Accounting Act 1935 and the Government Procurement Act 1998. The purpose of this legislation is to reduce waste and enhance efficiency when executing public expenditures. Throughout the budget execution phase, not only does each ministry conduct internal control, the DGBAS also leverages the accounting system to ensure the legality of all expenses and to monitor the expenditure execution process in all ministries. To eliminate fraud and waste, the DGBAS takes a very stringent approach to budget execution and control, to the extent that many government bureaucrats complain that the internal control and audit procedures have tipped the balance, overemphasising fraud prevention and compromising the public benefits expected from the expenditures involved. Some argue that the system is wasting taxpayer dollars without generating the intended public benefits (Kuo et al. 2013).

\section{Accounting and audit}

The accounting and audit phase ensures that the government's actual revenue and expenditures are aligned with the legal budget by detecting any fraud or negligence during budget execution, as well as monitoring the completed and incomplete budget programs. Theoretically, budget decision-makers should adjust the budget proposal for the coming year based on the past performance of budget execution. In reality, however, both government bureaucrats and legislators tend to focus more on budget preparation than on execution. They work very hard to get the annual budget passed in the Legislative Yuan, but, once the money is appropriated, they pay little attention to the performance of budget execution and seldom thoroughly review whether objectives have been met. For instance, according to the Financial Statement Act 2000, the auditor-general should submit a final audit report to the Legislative Yuan and, within a year of receipt, the Legislative Yuan should complete deliberation of that report. If deliberation is not completed within this time frame, the report is deemed deliberated and is automatically 
approved. However, looking back over the past 10 years, the Legislative Yuan failed to complete deliberation nine times. ${ }^{5}$ This exemplifies how the performance information collected in the accounting and audit phase fails to provide feedback to budget-makers in a timely manner.

\section{The local government budget process}

There are three levels of autonomous local government in Taiwan, with six special municipalities, 13 counties and provincial municipalities and 198 county municipalities and townships. The budgetary process at the local government level mirrors that for the central government, including the budget preparation, budget approval, budget execution and accounting and audit phases. Likewise, the entire procedure is regulated by the Budget Act, Financial Statement Act and Audit Act.

Most local governments in Taiwan face an enormous fiscal burden but enjoy only very limited fiscal autonomy. Taiwan has a unique 'one-whip' budgetary system - a legacy from the authoritarian era-under which the DGBAS holds the authority for appointment of all budgeting and accounting personnel in both central and local governments. Although the people elect local governors, they do not have the authority to appoint their own budgeting and accounting personnel. Furthermore, under this one-whip system, the DGBAS issues annual guidelines on the preparation and execution of public budgets-a binding document that stipulates budgetary preparation and execution for both central and local levels. When local governments prepare and execute their budgets, they have to abide by the DGBAS guidelines. Some scholars criticise this mechanism and argue that local government leaders should try to gain more autonomy in making budgetary decisions so as to better respond to the public's needs (Chen and Lu 2005; Ji 2008).

Meanwhile, some scholars argue that many local governments in Taiwan lack the fiscal discipline to safeguard taxpayer dollars and incentives to expand their revenue sources (Lin and Tsai 2003; Ji 2015). Many politicians continue spending money on large projects to please voters and are oblivious to the accumulated public deficit. Indeed, most voters care more about infrastructure projects and social welfare programs

5 Between fiscal years 2005 and 2014, only the audit report for fiscal year 2010 was deliberated and approved by the Legislative Yuan within a year of receipt. 
than about controlling public debt. What is even worse is that, when local governments are unable to pay public employees or contractors, the central government simply steps in by increasing intergovernmental grants or general revenue sharing, so that local governments do not go bankrupt. As a result, applying rational political calculations when facing fiscal crises, local governments have figured out that asking the central government for help is a much more convenient approach than increasing tax or cutting expenditures, which might antagonise voters (Jang 2006; Fang 2014). In this political reality, many local governments lack both the capacity and the motivation to properly allocate and manage their fiscal revenue. Some scholars therefore believe that the 'one-whip' regime can at least curtail certain irresponsible or inefficient expenditure items (Chen and $\mathrm{Lu}$ 2005). At the very least, the budgeting and accounting officials appointed by the DGBAS, from a more neutral and objective position, might be more capable of looking after the public purse.

In addition to the revenue shortage problem, another challenge facing local governments is the imbalance in revenue distribution. In Taiwan, most local revenue is derived from property taxes. Urban real estate prices are higher than rural prices, which generate greater property tax revenue, while rural and agricultural regions see smaller increases in real estate prices so their local governments collect less revenue. Through intergovernmental fiscal transfers, including general revenue sharing and grants, the central government can shift this balance. Yet, because of the mechanism for such transfers, some local governments become overly reliant on the central government's financial support and fail to establish their own fiscal autonomy. To elaborate further, although real estate prices in certain regions have increased along with local economic development, local governments are often reluctant to adjust their tax base accordingly, so their property tax revenue does not grow in conjunction with economic growth. It is necessary to request local governments to periodically re-examine their property tax structure and to expand revenue sources so they can develop greater fiscal autonomy.

The lack of rational budgetary decision-making is the third challenge in the local budgeting process. Except for a very few governments (such as the Taipei City Government), the overall quality of local budgetary regimes is much poorer than at the central government level. There are two reasons for this disparity. First, local councillors are generally not as qualified as central government legislators, so their budgetary oversight capability requires much improvement. For instance, Miaoli County 
Council has not made any modifications to the general budget proposed by the executive branch in the past 23 years, despite having one of the country's heaviest debt burdens (Liberty Times Net 2003). Second, the media and most civic groups tend to pay more attention to budgetary decisions and processes at the central government level and provide less oversight of local government activities. Consequently, the level of fiscal transparency and public accountability in local government budgeting is low (Su et al. 2010).

\section{Continuing budget reforms}

Taiwan continues to undertake budget reform, including democratisation of public budgeting following the lifting of martial law in the 1980s and the performance-driven budgeting reform influenced by NPM theory in the 1990s. While these reforms are ongoing, two of the most prominent recent developments in Taiwan are participatory budgeting and performance auditing.

\section{Participatory budgeting}

During Taiwan's nationwide nine-in-one election in 2014, many candidates proposed a policy of participatory budgeting, which received wide support and was particularly popular among younger voters. Participatory budgeting was first developed in Brazil in the late 1980s and has since become a global trend. It is a process of democratic deliberation and budget decision-making in which ordinary people decide how to allocate a certain portion of the public budget. Participatory budgeting has the potential to enhance participatory democracy, social inclusion, fairness in allocating social resources and public sector innovation.

The participatory budgeting models adopted in Taiwan can be categorised into three types: the councillors' budget quota model, the executive grant model and the integrative budget process model. Under the councillors' budget quota model, local councillors enjoy the right to propose budgeting bills within a given quota and earmark them for certain local projects or programs. In the early days, such proposals were rarely scrutinised and the executive body simply executed the relevant budget. Yet some of the proposals represented pure 'pork barrelling' and, when investigated, were found to be wasteful and fraudulent (Tang et al. 2002). Some councillors 
even used the public funds to consolidate personal alliances. Since then, there has been more stringent oversight of these budget quota measures. Generally speaking, however, as long as the spending program proposed by the councillor does not exceed his or her budget quota, the executive branch allocates the budget based on the councillors' proposals. With the shift to participatory budgeting, the so-called councillors' budget quota model requires councillors to take the initiative to refer a part of their budget quota to their constituents to decide how to use the money. With the help of government administrators, citizens propose, discuss and vote for the allocation of the budget quota; the executive branch then executes the chosen programs. This model is similar to the participatory budgeting practices in Chicago and New York. ${ }^{6}$

Taiwan has promoted participatory budgeting since 2015, and a few municipal councillors are developing trial projects in their districts. Although the budget quota is small, all citizens in the community can jointly decide how to spend the public dollars. Compared with the previous situation, when councillors could earmark budget items, this type of participatory budgeting is a great improvement in local governance. Some trial cases have received positive support. While city councillors are initiating these cases, the executive branch also plays a key role, such as through promoting the process, helping citizens evaluate and improve the proposals and enhancing program feasibility. Continued monitoring is required to understand whether this is only for show among councillors or whether councillors are genuinely willing to devolve some budget decision-making to the public in future.

The second model of implementing participatory budgeting is the executive grant model. Each central government ministry or local government department can allocate a budget to grant non-governmental organisations (NGOs) funds to be spent through participatory budgeting. New Taipei City provides an example. Beginning in the second half of 2015, the city's economic development department offered grants

6 In 2009, Alderman Joe Moore of Chicago's 49th Ward launched the Participatory Budgeting Project (PBP) by allocating US $\$ 1.3$ million of his discretionary fund for the residents of his ward. Citizens gathered to discuss, deliberate and vote into implementation projects that were then executed by the administration. This experience was then brought to New York. Harlem-based Community Voices Heard, founded more than 20 years ago, initiated PBPs. So far, more than half of all city council members support the process. City council members commit their discretionary funds, ranging between US $\$ 1$ million and US\$2 million, to PBPs. One provision states that these proposals are limited to the construction or updating of public infrastructure projects that are in use for at least five years. 
to two non-profit organisations to advocate, orchestrate and support participatory budgeting in relation to energy conservation. ${ }^{7}$ The two selected organisations helped the public formulate, discuss, review and vote for proposals. While it is mainly the government agency that executes the selected projects, the public and NGOs can also take part. Based on this model, both the urban development department of the Taichung City Government and the Research, Development and Evaluation Commission of the Kaohsiung City Government have commissioned university scholars to embark on, respectively, the Taichung Central District Participatory Budgeting Project and the Public Participation and Empowerment for 2017 Hama Star EcoMobility World Festival.

Both the councillors' budget quota and the executive grant models are designed to promote participatory budgeting through individual projects without changing the government's budgetary regime. Taking a more comprehensive approach, the third model integrates participatory budgeting into the government's formal budgetary preparation process, and is therefore the most challenging of the three models. One representative example is the participatory budgeting procedure initiated by the Taipei City Government and led mainly by the Department of Civil Affairs since 2015. Public meetings and training sessions are held in district-level offices and citizens are invited to submit their budget proposals in person at the district offices or through an online platform. Citizens get to vote and rank the proposals, while government officials assist in refining the proposals' content and each bureau prepares the budget estimates. The proposals are then submitted to the Taipei City Government's Public Participation Committee for final reading. Once a proposal is passed, it is incorporated into the city government's general budget proposal, which is then submitted to the city council for approval. The year 2015 was the first year Taipei City had undertaken a participatory budget and only a few hundred participants were involved, so it is too early to fully understand and measure its impact.

No matter which model is applied, participatory budgeting still accounts for only a very small portion of Taiwan's overall budget and the number of participants is but a tiny fraction of the total population. This is similar to the development of participatory budgeting in most other countries (Su et al. 2015). It is fair to say that participatory budgeting plays mainly

7 The two non-profit organisations are Yonghe Community College and Ludi Community College. 
an educational role for democratic participation and a less substantial role in budget allocation. For participatory budgeting to become more influential in the future, the level of public participation should be further elevated-focusing more on dialogue and engagement throughout the process than on the formality of proposing bills and casting votes. Government agencies should also help to empower people by providing more supportive measures.

\section{Performance auditing}

In the past, Taiwan's audit agencies mainly conducted compliance audits, focusing on supervising the legality of budget execution, such as whether there was any financial illegality or delinquency regarding where and how the funds were spent. To enhance the value of audit and to stay abreast of global trends, audit agencies have begun transforming their roles from traditional oversight to providing insight into financial management, key trends and emerging challenges. To become better equipped in playing these new roles, audit agencies in Taiwan are ramping up efforts to develop performance auditing by assessing thoroughly the performance of budget execution.

Performance auditing is much more challenging than compliance auditing. For compliance auditing, auditors only have to be knowledgeable about the regulatory framework, as their work mainly entails reviewing whether an agency is adhering to laws and regulations during the budget execution phase. Performance auditing is about assessing the performance of specific expenditure programs. For example, did a program meet its objectives and is the value of public money maximised? Performance auditing is no longer just about laws and regulations, but also requires interdisciplinary knowledge and expertise, especially when it comes to cross-agency programs. Auditors also have to understand how the work of different agencies relates to one another and to grasp the 'big picture' of how the program should be executed. In other words, auditors in performance auditing must possess in-depth knowledge of policies and have familiarity with the methods of performance or program evaluation. This is a new challenge for auditors, which also implies new auditing risks.

At the same time, performance auditing also presents new challenges for auditors to maintain audit independence- a core value for auditing bodies. In the past, when auditors conducted mainly compliance audits, they could easily come to an objective judgment about legal compliance issues without much involvement by the audited entity. In contrast, 
in the case of performance auditing, auditors have to actively engage and communicate with audited entities to gain their trust so they can obtain the necessary information for the performance auditing reports. Moreover, the performance auditing reports-unlike the neutral, objective compliance reports-tend to have a degree of subjectivity and hence are more controversial, and can sometimes compromise audit independence. Therefore, in the pursuit of performance auditing, it is important that auditing agencies learn how to interact with audited entities while also maintaining audit independence and impartiality.

\section{Conclusion}

Taiwan's current tax burden per taxpayer is low, leaving the government with serious revenue shortages compared with previous years given the increasing demand for government services. The government has to pinch every penny possible to maximise revenue and struggles to meet the needs of the people. Despite decades of reforms, including both budget democratisation and performance-led budgetary reform, the current government's budgetary regime faces challenges. In particular, both the executive and the legislative bodies still undervalue the importance of the assessment stage of major spending programs, such as the practice of CBA. In addition, because of political party confrontation at the budget approval phase, politics overruns rational decision-making, especially among local councillors. As for the budget execution phase, a change in mindset is required for government agencies to move away from the overly conservative, fraud-preventative approach to effective budget control.

The two current budgetary reforms-participatory budgeting and performance auditing - share the objective of maximising the value of taxpayer dollars. Participatory budgeting aims to enhance public accountability and align government expenditure more closely to people's needs by incorporating citizen participation into the budgeting process. Performance auditing aims to transform the role and function of auditing bodies from providing oversight to providing insight and foresight.

This chapter has pointed out a number of problems in Taiwan's public budget system. But, if we look at the overall picture, we see steady improvement in the budgetary institutions over time. As budgetary reform scholars in the United States have commented, wherever we have walked, traces are left behind (Rubin 1990; Posner 2007). When we study budgetary 
decisions and reforms in Taiwan, the incremental budgeting model is the most common, under which gradual changes are made step by step rather than through radical reforms. Whether it is the democratisation of public budgeting or efficiency-led budgeting reforms in the past, or the current interest in participatory budgeting and performance auditing, each reform has achieved at least some of its objectives and, at the same time, has updated the budget policy reform agenda, identifying more goals to be pursued.

\section{References}

Chao, O. H. 2005. 'A study on how to professionalize the committee function and uncover the party coordination in Legislative Yuan'. Journal of Social Sciences and Philosophy 13(1): 37-54.

Chen, J.-K. and Y.-C. Lu. 2005. The Restructuring of One-Whip System under Governmental Reform. Taipei: Ministry of Civil Service.

Department of Statistics. 2017. Yearbook of Financial Statistics, 2016. Taipei: Ministry of Finance.

Fang, K.-H. 2014. 'Mutual consolidation of local fiscal behaviors and institutions: Reinterpreting the fiscal predicament of local government'. In T.-T. Su (ed.) Challenges and Trends in Local Governance: Taiwan's experiences. Taipei: Taiwan Foundation for Democracy.

Hawang, S.-D. 2002. 'The improvement of congress: Two waves of reform in the Legislative Yuan'. New Era Think Tank Forum 17: 42-56.

Jang, C.-L. 2006. 'Evaluation on the problems of implementing the general law on local taxation: An application of the third generation implementation theory'. Chinese Local Self-Governance 59(1): 4-23.

Ji, J.-C. 2008. 'The one-whip system and local government'. Intergovernmental Relationship Research Newsletter 1: 5-7.

Ji, J.-C. 2015. 'Financial issues and strategies in Taiwan: Comparison between municipality and county/city'. Chinese Local Government 68(4): 3-27.

Kuo, Y.-Y., L.-C. Hung and K.-H. Fang. 2013. Improving DGBAS's Financial Management System in Taiwan. Taipei: Research, Development and Evaluation Commission. 
Liberty Times Net. 2003. 'Miaoli is not afraid of mounting debt at all; it did not cut its general budgets in 23 consecutive years'. [In Chinese]. Liberty Times Net, 3 January. Available from: news.ltn.com.tw/news/ politics/paper/1067871 (accessed 3 January 2017).

Lin, J. K.-T. and C.-Y. Tsai. 2003. 'Fiscal discipline of the local governments and the revenues and expenditures classification'. Journal of Public Administration 9: 1-33.

Organisation for Economic Co-operation and Development (OECD). 2016. Revenue Statistics 2016. Paris: OECD Publishing.

Posner, P. L. 2007. 'The continuity of change: Public budgeting and finance reforms over 70 years'. Public Administration Review (NovemberDecember): 1018-29. doi.org/10.1111/j.1540-6210.2007.00793.x.

Rigger, S. 1999. Politics in Taiwan: Voting for democracy. London: Routledge. doi.org/10.4324/9780203449028.

Rubin, I. S. 1990. 'Budget theory and budget practice: How good the fit?’ Public Administration Review (March-April): 179-89. doi.org/ $10.2307 / 976865$.

Su, T.-T. 1996. The Study of Public Budgeting. Taipei: Hwa Tai Publishing.

Su, T.-T. 2007. 'Public budgeting reform in Taiwan'. In G. Caiden and T.-T. Su (eds) The Repositioning of Public Governance: Global experience and challenges. Taipei: Taiwan Public Affairs Center.

Su, T.-T., W. Sun and H.-F. Tsai. 2015. The Feasibility of Participatory Budgeting Model in Taiwan. Taipei: National Development Council.

Su, T.-T., C.-D. Tso and C.-J. Chen. 2010. The Analytical Framework and Evaluation of Government Transparency. Taipei: Research, Development and Evaluation Commission.

Tang, C.-P. T., C.-L. Wu and K.-C. Su. 2002. 'Divided government and local democratic administration: Budget for local infrastructure, local factions, and pork-barrel politics in Taichung County'. The Chinese Public Administration Review 12(1): 37-76.

Wang, Y.-L. 2002. 'The role of political party and operation of party caucuses in congress'. The Taiwan Law Review 86: 82-96. 
This text is taken from Value for Money: Budget and financial management reform in the People's Republic of China, Taiwan and Australia, edited by Andrew Podger, Tsai-tsu Su, John Wanna, Hon S. Chan and Meili Niu, published 2018 by ANU Press, The Australian National University, Canberra, Australia. 